J. Perinat. Med.

1 (1973) 213

\title{
Rapid specific determination of amniotic fluid lecithins as a test of fetal lung maturity*
}

\author{
Geno Kynast, Erich Z. Saling \\ Unit for Perinatal Medicine at the Free University of Berlin \\ (Head: Prof. Dr. E. Z. Saling)
}

Received: March 30, 1973. Accepted: May 29, 1973.

Normal respiratory function in the newborn depends on the development of adequate amounts of surfactant substances in the alveoli. The changes in the phospholipid content of the fetal lung during gestation correspond to those in the amniotic fluid. Therefore several methods have been developed to determine the amount of amniotic fluid lecithins, which are major constituents of surfactant substances and which, in contrast to the other main phospholipids, are greatly increased in the last trimester of gestation, especially near term.

GLUCK et al. [3] have described a method for estimating the liquor lecithin/sphingomyelin ratio (L/S ratio). Some authors corroborated their results $[1,5,7,11]$; others came to different conclusions [4, 8, 12]. Gusdon and WAITE [4] proposed a colorimetric method for the determination of phospholipids in amniotic fluid, $70 \%$ of which are thought to consist of lecithins. There is no doubt that analysis, based on such measurements, is both unsatisfying and unreliable. In addition, determination of phosphorus is unspecific. Therefore, complete separation of lecithins before determination is necessary. Some authors have achieved this objective by separating lecithins from other phospholipids using thin-layer chromatography and measurement of phosphorus in the eluate from silica gel scraped from the plate. The disadvantages of this method are the long-time periods involved, recovery problems (recovery: $86-92 \%$ [1]) and high liquor volumes ( 8 to $18 \mathrm{ml}[1,8,9]$ ).

These facts give an idea of what is needed: $\mathbf{A}$ method for direct determination of lecithins

\section{Curriculum vitae}

Geno Krnast - born 1937 in Berlin. Studied chemistry in Berlin and Saarbrücken, received engineers diploma in 1963, graduated (Dr. Ing.) from the Technical University of Berlin in 1967 with the thesis: "Chelating ionexchange resins for separation of radionuklides". For three years worked as an analytical chemist in industrial pharmaceutical research. Later studied medicine at the Free University of Berlin. Since 1971 bas conducted biocbemical investigations in the Unit for Perinatal Medicine under Prof. SAling.

which works quickly and specifically. A step in this direction has been made by BHagwanan, Fahmy and Turnbull [2], but the time requirement and the analytical expense are still too high, and lecithins are not determined directly but estimated from phosphorus content of thin-layer spots.

\section{Materials and methods}

133 amniotic fluid specimens from 125 pregnancies were examined to determine the correlation between concentrations of lecithins and gestational age. This paper gives mainly details of procedure; further clinical consequences and methodological aspects will be discussed in following publications.

* This work comprises major parts of the medical doctoral thesis of G. KYNAST. 


\subsection{Principle}

Lecithins are extracted from amniotic fluid, separated from other phospholipids by thinlayer chromatography and then directly determined and evaluated by means of reflectance measurements and data processing.

The procedure consists of four steps:

a) Extraction from amniotic fluid and preparation of standards,

b) spotting of extracts, development and staining of thin-layer plates,

c) densitometric measurement,

d) programming of reflectance values of reference standards and computation of lecithins in assay materials from a calibration curve.

\subsection{Reagents and set up}

Reference standard solutions of lecithins from eggs, puriss. (MERCK) or $\beta, \gamma$-dipalmitoyl- $\alpha$-lecithin, puriss. (FLUKA) contained $0.01 \mu \mathrm{g} / \mu \mathrm{l}$ to $0.12 \mu \mathrm{g} / \mu \mathrm{l}$ of active material dissolved in chloroform/methanol/water $(65 / 25 / 4 \mathrm{v} / \mathrm{v} / \mathrm{v})$.

The whole procedure should be performed at about $5^{\circ} \mathrm{C}$; the amniotic fluid should be stored in a low-temperature refrigerator or extracted before storage.

\subsubsection{Semimicro-extraction}

Samples are centrifuged at $3000 \mathrm{rpm}$. for 5 minutes and the liquor decanted from the sediment. Then exactly $0.25 \mathrm{ml}$ of amniotic fluid, $1.0 \mathrm{ml}$ chloroform and $1.0 \mathrm{ml}$ methanol are pipetted into a graduated $1 \mathrm{ml}$ centrifuge tube, which is then stoppered firmly and shaken thoroughly for 10 minutes. After separation of phases, which can be accelerated by centrifuging at $1000 \mathrm{rpm}$., the volume of the chloroform layer (lower) is read off and a sample is taken by an AGLA micrometer syringe (VETTER) with a $5 \mathrm{~cm}$ steel needle.

\subsubsection{Macro-extraction}

If the available volume of amniotic ffuid is not limited, $2.0 \mathrm{ml}$ of centrifugate, $4.0 \mathrm{ml}$ chloroform and $4.0 \mathrm{ml}$ methanol are pipetted into a graduated $1 \mathrm{ml}$ centrifuge tube and treated as described above. The mean volume of the chloroform layer after extraction as calculated from 146 experiments is $5.13 \pm 0.09 \mathrm{ml}$.

\subsubsection{Spotting and staining}

For thin-layer chromatography, twelve $1.5 \mathrm{~cm}$ bands are marked on precoated $25 \times 25 \mathrm{~cm}$ thinlayers of silica gel (MERCK), with the starting line set at a height of $3 \mathrm{~cm}$ and the stop-line marked with a steel needle at $13 \mathrm{~cm}$ to obtain a
$10 \mathrm{~cm}$ running path. After this, the thin-layer is heated on a hot plate to about $70^{\circ} \mathrm{C}$; reference standards $(0.01 ; 0.02 ; 0.04$ and $0.08 \mu \mathrm{g}$ lecithins/ $\mu \mathrm{l})$ are spotted on four bands. The remaining eight are spotted with $50 \mu \mathrm{l}$ of two extracts from the assay samples to obtain four values for each sample. If the lecithin content is low, 100 or $200 \mu \mathrm{l}$ of extract are spotted. The spots should be similar in size. Chromatograms are developed in a freshly mixed solvent system chloroform/ methanol/water $(65 / 25 / 4 \mathrm{v} / \mathrm{v} / \mathrm{v})$, and allowed to dry for 10 minutes. Lecithins can be stained either by $(\mathrm{Rf} .=0.4)$ :

A) Iodine vapour (5 to 10 minutes),

B) or separation on impregnated plates (5\% ammonia sulfate aqueous solution) and development by heating for 10 minutes to $180^{\circ} \mathrm{C}$,

C) or Folin-Crocalteu's phenol reagent (MERCK).

\subsection{Evaluation}

When interpreted quickly after preparation, iodinestained plates (staining method A) give the best results. Plates prepared with staining methods B or C do not fade, but differentiation is not as good. Measurements were carried out with an apparatus consisting of a Spectral Photometer PMQ II-ZEIss combined with a CAMAGZ-Scanner. A Hewlett-Packard 9810 A computer with printer alpha ROM and statistic block was used for evaluation. Gaugings were made of the relative reflectance values of lecithin in the center of the spots against background.

The instrumental data was as follows: Set up: lamp-monochromator-sample-amplifier-indicator; wavelength: $440 \mathrm{~nm}$ (staining methods $B$ and $C$ : $560 \mathrm{~nm}$ ); monochromator slit: $0.5 \mathrm{~mm}$, with no diaphragms for slit-height reduction*.

The computer prints $\mu \mathrm{g}$ lecithins/spot. The content of the lecithins in the amniotic fluid (AF) samples may be determined from these values by the following equation:

$$
\frac{[\mu \mathrm{g} / \mathrm{spot} \times][\mathrm{ml} \mathrm{extract}] \times 100}{[\mu \mathrm{s} / \mathrm{spot}] \times[\mathrm{ml} \mathrm{AF}]}=\frac{[\mathrm{mg} \mathrm{lec.}]}{[100 \mathrm{ml} \mathrm{AF}]}
$$

* For details of interpretation and computation see [6]. 
Arithmetic example for a macro determination:

$$
\begin{gathered}
\frac{1.27 \mu \mathrm{g} \times 5.15 \mathrm{ml}}{50.0 \mu \mathrm{l} \times 2.0 \mathrm{ml}}=0.0654 \mu \mathrm{g} / \mu \mathrm{l} \\
=6.54 \mathrm{mg} \text { lecithins } / 100 \mathrm{ml} \mathrm{AF}
\end{gathered}
$$

\section{Results and discussion}

Our results show the increase of amniotic fluid lecithins especially between 37 and 40 weeks gestation, in cases where the fetal condition is not disturbed. The levels of lecithins in the predelivery period ( 39 to 43 weeks) ranged from 3.0 to $30 \mathrm{mg} / 100 \mathrm{ml}$; in some cases of 40 and more weeks, values of more than $50 \mathrm{mg} /$ $100 \mathrm{ml}$ were observed. The mean of predelivery levels of lecithins is $9.3 \mathrm{mg} / 100 \mathrm{ml}$ when compared to egg lecithins, and $10.2 \mathrm{mg} / 100 \mathrm{ml}$ when $\beta, \gamma$-dipalmitoyl- $\alpha$-lecithin was taken as a standard, because this standard gives about $10 \%$ higher results. A comparison with the composition of human lecithins as standard will be performed as soon as possible. Fig. 1 shows the mean concentration curve of 133 amniotic fluid samples from 125 patients during gestation. Broken lines show the 95 per cent confidence limits.

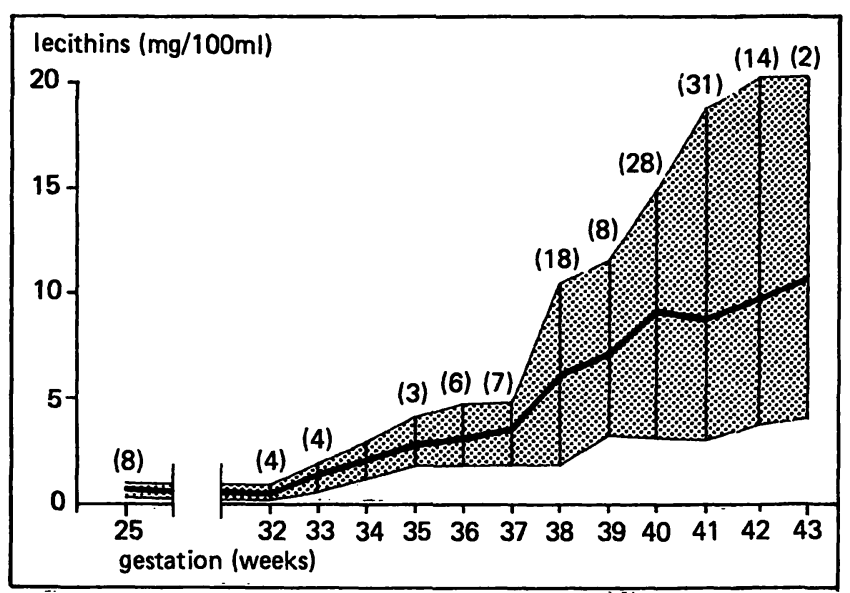

Fig. 1. Mean concentrations of lecithins in amniotic fluid during gestation. Broken lines show the 95 per cent confidence limits. ()$=$ number of samples.
Infants with respiratory complications had concentrations of lecithins clearly below $3.0 \mathrm{mg}$ / $100 \mathrm{ml}$. The detection limit of the proposed method was $0.2 \mathrm{mg} / 100 \mathrm{ml}$ (staining method A); therefore these groups are easily distinguishable.

The relative standard deviation calculated from results compiled by electronic data processing was about $12 \%$, and the recovery of standard egg lecithins was $104 \pm 13 \%$. The time required for series analyses was approximately $80 \mathrm{~min} /$ plate corresponding to $10 \mathrm{~min} /$ analysis (excluding developing time of $75 \mathrm{~min} /$ plate). One technican can process 4 plates, corresponding to 32 analyses, per day, so it is suitable for routine use, as already done in our laboratory. Urgent determinations can be carried out in about 2 hours if plates, already spotted with standards, are available. The required time for the different steps of the method is given in Tab. 1.

The simplification of the purification of the amniotic fluid is an important advance in this. method, as samples for spotting are taken directly from the chloroform layer. Another favourable point is the semimicro-technique, which makes possible the determination of lecithins from less. than $0.5 \mathrm{ml}$ of amniotic fluid, and is recommended when the volume of fluid is limited. Such a problem may occur in cases where transabdominal amniocentesis or transcervical micro-puncture accoding to SALING [10] is difficult and/or only small samples are available. The proposed method makes possible direct, specific and quantitative determination of lecithins independent of other phospholipids. Lecithins are measured directly against standard lecithins, so problems of determining corresponding values of the content of lecithins from phosphorus are avoided. Blood. or meconium contaminated samples can be examined without difficulties. This is of great importance, particularily in cases prone to

Tab. 1. Time required for steps of determination of lecithins.

\begin{tabular}{lcccccc}
\hline & $\begin{array}{c}\text { preparation and } \\
\text { extraction }\end{array}$ & spotting & measurement & evaluation & $\begin{array}{c}\text { total working developing } \\
\text { time }\end{array}$ & $\begin{array}{c}\text { dime } \\
\text { tim/plate }\end{array}$ \\
min/analysis & 20 & 40 & 10 & 10 & 80 & 75 \\
\hline
\end{tabular}


postnatal lung complications when the amniotic fluid contains meconium.

Together with other parameters, we use the results of lecithin determinations to decide whether the surfactant factor is present in sufficient quantities such that the baby can be born or wether delivery should be delayed. These questions can be of clinical importance in high

\section{Summary}

The proposed method makes possible the direct, specific and quant tative determination of lecithins independently of other phospholipids. Lecithins are measured directly against standard lecithins. Problems of determining corresponding values of the content of lecithins from phosphorus are thus avoided. Blood or meconium contaminated samples can be examined without difficulty. Lecithins are extracted from the amniotic fluid, separated from other 'phospholipids by thin-layer chromatography, and after staining of plates directly determined and evaluated by means of reflectance measurements and data processing.

The procedure consists of four steps:

a) Extraction from amniotic fluid and preparation of standards,

b) spotting, development and staining of thin-layer plates,

c) densitometric measurements,

d) programming of reflectane values of reference standards and computation of lecithins in assay materials from a calibration curve.

The simplification of the purification of the amniotic fluid is an important advance in this method, as samples for spotting are taken directly from the extraction solution layer. Another favourable point is the semimicro-technique, which makes possible a determination of lecithins from less than $0.5 \mathrm{ml}$ of amniotic fluid, and is recommended when the volume of fluid is limited. Such a problem may occur in cases where transabdominal amniocentesis or transcervical micro-puncture is hindered and leads to only small samples being obtained. risk cases, such as imminent premature labor, dysmature fetus or placental insufficiency.

There is no doubt that the required equipment is expensive but a Spectral Photometer PMQ IIZEISS or a similar apparatus and a HEwLETTPACKARD 9810 A computer are customary multipurpose instruments used in many laboratories.

Measurements were carried out with an apparatus consisting of a Spectral Photometer PMQ II-ZErss combined with a Camag-Z-Scanner. A Hewletr-Packard 9810 A computer with printer alpha ROM and statistic block was used for evaluation. Gaugings were made of the relative reflectance values of lecithins in the center of the spots against background.

Our results show the increase in amniotic fluid lecithins especially between 37 and 40 weeks gestation in cases where the fetal condition is not disturbed (Fig. 1). The levels of lecithins in the predelivery period (39-43 weeks) ranged from 3 to $30 \mathrm{mg} / 100 \mathrm{ml}$ amniotic fluid; in some cases values of more than $50 \mathrm{mg} / 100 \mathrm{ml}$ were observed. Infants with respiratory difficulties had concentrations of lecithins clearly below $3.0 \mathrm{mg} /$ $100 \mathrm{ml}$. The detection limit of the proposed method was $0.2 \mathrm{mg} / 100 \mathrm{ml}$; therefore these groups are easily distinguishable.

The relative standard deviation calculated from results compiled by electronic data processing was about $12 \%$.

The time required for series analyses was approximately $80 \mathrm{~min} /$ plate corresponding to $10 \mathrm{~min} /$ analysis, excluding the developing time of $75 \mathrm{~min} / \mathrm{plate}$ (Tab. 1). One technican can process 4 plates, corresponding to 32 analyses, per day, so it is suitable for routine use as already done in our laboratory.

Together with other parameters we use the results of the determinations of lecithins for estimating the most suitable time of delivery, especially in high risk pregnancies.

Keywords: Amniotic fluid, fetus, lecithins, lung maturity, phospholipids, thin-layer chromatography (quantitative).

\section{Zusammenfassung}

Schnelle spezifische Bestimmung der FruchtwasserLezithine als Test fetaler Lungenreife

Die beschriebene Methode ermöglicht die direkte, spezifische und quantitative Bestimmung von Lezithinen ohne Störung durch andere Phospholipide. Die Substanzen werden direkt gegen Lezithin-Standards gemessen und so Schwierigkeiten bei Umrechnung von Phosphor- in Lezithin-Gehalt vermieden. Auch blut- oder mekoniumhaltige Proben können untersucht werden. Die Lezithine werden aus dem Fruchtwasser extrahiert, von den anderen Phospholipiden dünnschichtchromatographisch getrennt, nach Anfärbung der Platten durch Remissionsmessungen bestimmt und mit Hilfe eines Computer-Programms aus- gewertet. Das Verfahren läßt sich in vier Abschnitte gliedern:

a) Extraktion des Fruchtwassers und Herstellung der Eichlösungen,

b) Auftragen der Extrakte, sowie Anfärben und Entwickeln der Dünnschichtplatten,

c) Auswertung durch Messung der Remission,

d) Eingabe der Remissionswerte der Eichflecke in ein Computerprogramm zur Berechnung einer Eichgeraden aus der die Lezithingehalte des Probenmaterials exmittelt werden.

$\mathrm{Da}$ die Proben für das Auftragen direkt aus der Extraktionsmittel-Phase entnommen werden resultiert eine 
beachtliche Vereinfachung der Fruchtwasseraufbereitung. Ein weiterer wichtiger Punkt ist die Halbmikro-Arbeitstechnik, durch die eine mehrfache Bestimmung der Lezithine aus weniger als $0,5 \mathrm{ml}$ Fruchtwasser ermöglicht wird. Das ist wichtig für die manchmal nur erschwert durchführbare transabdominale Amniozentese oder die transzervikale Mikropunktion, wo in einigen Fällen nur geringe Fruchtwassermengen gewonnen werden können.

Die Messungen wurden mit einer Apparate-Kombination bestehend aus einem Spektralphotometer PMQ II-ZEISS und einem Camag-Z-Scanner durchgeführt. Ein HewLETt-Packard 9810 A Tischrechner mit Drucker, Alpha ROM und Statistic Block wurde zur Auswertung benutzt. Gemessen wurden die relativen Remissionswerte im Fleckenzentrum gegen den Untergrund.

Die Ergebnisse bestätigen das Anwachsen des Lezithingehaltes des Fruchtwassers besonders zwischen der 37. und 40. Gestationswoche (Abb.1). Die Lezithin- gehalte in der Vorgeburtsperiode (39.-43. Woche) lagen in einem Bereich von 3,0 bis $30 \mathrm{mg} / 100 \mathrm{ml}$ Fruchtwasser, in einigen Fällen auch über $50 \mathrm{mg} / 100 \mathrm{ml}$. Bei Kindern mit respiratorischen Komplikationen lagen die Lezithinkonzentrationen deutlich unter $3,0 \mathrm{mg} / 100 \mathrm{ml}$. Da die Nachweisgrenze der Methode bei $0,2 \mathrm{mg} / 100 \mathrm{ml}$ liegt, sind solche Fälle leicht zu erkennen. Die relative Standardabweichung der Ergebnisse liegt bei 12\%. Der Zeitbedarf für Serienanalysen beträgt $80 \mathrm{~min} /$ Platte entsprechend $10 \mathrm{~min} /$ Analyse, ausschließlich der Entwicklungszeit von 75 min/Platte (Tab. 1). Eine Laborkraft kann vier Dünnschichtplatten, entsprechend 32 Analysen pro Tag bearbeiten. Damit ist die Methode zur Routinekontrolle geeignet. Als solche wird sie bei uns angewendet. $\mathrm{Zu}$ sammen mit anderen Parametern ziehen wir die Ergebnisse besonders in Risikofällen heran, wo die Frage nach dem bestgeeigneten Zeitpunkt für eine Geburtseinleitung gestellt ist.

Schlüsselworte: Dünnschichtchromatographie (quantitative), Fetus, Fruchtwasser, Lezithine, Lungenreife, Phospholipide.

\section{Résumé}

Définition spécifique rapide des lécithines du liquide amniotique pour tester la maturité pulmonaire foetale La méthode décrite permet la définition directe, spécifique et quantitative des lécithines sans trouble causé par d'autres phospholipides. Les substances sont directement mesurées d'après des standards de lécithine, de qui évite les difficultés d'un calcul de conversion du taux de phosphore en taux de lécithine. Des prélèvements contenant du sang ou du méconium peuvent être également analysés. Les lécithines sont extraites du liquide amniotique, séparées des autres phospholipides par chromatographie de couches minces, définies après coloration des plaques par des mesurages de rémission et évaluées à l'aide d'un programme de computer. Le procédé s'effectue en quatre étapes:

a) Extraction du liquide amniotique et établissement de la solution-étalon,

b) Application des extraits, développement et coloration des plaques de couches minces,

c) Evaluation par la mesure de rémission,

d) Transmission des valeurs de rémission du spot étalon dans un programme de computer pour le calcul d'une droite étalon permettant d'évaluer les taux de lécithine des spécimens prélevés.

Les spécimens appliqués étant prélevés directement de la phase de substance d'extraction, cela simplifie considérablement la préparation du liquide amniotique. Un autre point intéressant résulte de la méthode semi-micro employée qui permet d'analyser à plusieurs reprises les lécithines à raison d'un volume de liquide amniotique inférieur à $0,5 \mathrm{ml}$. Ceci est important pour l'amniocentèse transabdominale parfois très difficile à réaliser ou pour la microponction transcervicale ou il n'est possible dans certains cas que de prélever des quantités très réduites de liquide amniotique.

Les mesures ont été effectuées à l'aide de plusieurs appareils comprenant un spectrophotomètre PMQ II-ZEISSet un Camag-Z-Scanner. Une calculatrice sur pupitre Hewlett-Packard 9810 A avec imprimante, Alpha ROM et Statistic Block a été utilisée pour l'évaluation des données. Ont été mesurées les valeurs de rémission relatives dans le centre du spot contre le fond.

Les résultats confirment la hausse du taux de lécithine du liquide amniotique surtout entre les 37 et 40èmesemaines de gestation (fig. 1). Les taux de lécithine dans la période prénatale (39.-43. semaine) oscillent entre 3,0 et $30 \mathrm{mg} / 100 \mathrm{ml}$ de liquide amniotique et dépassent même dans quelques cas $50 \mathrm{mg} / 100 \mathrm{ml}$. Chez les enfantssouffrant de complications respiratoires, les concentrations de lécithine sont sensiblement inférieures à. $3,0 \mathrm{mg} / 100 \mathrm{ml}$. La limite de démonstration de la méthode. se situant aux alentours de $0,2 \mathrm{mg} / 100 \mathrm{ml}$, il est facile de dépister de tels cas. L'erreur standard relative est de 12 pour cent dans les résultats obtenus. Le temps requis. pour des séries d'analyses est de $80 \mathrm{mn} /$ plaque correspondant à $10 \mathrm{mn} /$ analyse, non compris la durée de développement de $75 \mathrm{mn} /$ plaque (tab. 1). Une personne de. laboratoire peut évaluer par jour quatre plaques de couches. minces, soit 32 analyses. La méthode convient donc au contrôle de routine et est utilisée comme telle dans nos. services. Nous aidant aussi d'autres paramètres, nous $y$ avons particulièrement recours dans les cas suspects ou on doit décider le moment le plus recommandé pour un. déclenchement d'accouchement.

Mots-clés: Chromatographie de couches minces (quantitative), foetus, liquide amniotique, lécithine, maturité pulmonaire, phospholipide. 


\section{Bibliography}

[1] Bhagwanani, S. G., D. Fahmy, A. C. Turnbull: Prediction of neonatal respiratory distress by estimation of amniotic fluid lecithin. Lancet I (1972) 159

[2] Bhagwanani, S. G., D. Fahimy, A. C. Turnbull: Quick determination of amniotic fluid lecithin concentration for prediction of neonatal respiratory distress. Lancet II (1972) 66

[3] Gluck, L., M. V. Kulovich, R. C. Borer, P. H. BrenNer, G. H. ANDerson, W. N. Spellacy: Diagnosis of respiratory distress syndrome by amniocentesis. Amer. J. Obstet. Gynec. 109 (1971) 440

[4] Gusdon, J. P., B. M. Waite: A colorimetric method for amniotic fluid phospholipids and their relationship to the respiratory distress syndrome. Amer. J. Obstet. Gynec. 112 (1972) 62

[5] Hobbins, J. C., W. Brock, L. Speroff, G. G. ANderson, F. Caldwell, B. Caldwell: L/S ratio in predicting pulmonary maturity in utero. Obstet. and Gynec. 39 (1972) 660

[6] Kynast, G., J. W. Dudenhausen: Bestimmung von Aminosäuren in Fruchtwasser- und Blutproben durch direkte quantitative Dünnschichtchromatographie mit elektronischer Auswertung. Z. Klin. Chem. Klin. Biochem. 10 (1972) 573

17] Lorenz, U., H. Ruetrgers, M. Fromme, B. LehNERT, F. KuBLI: Phospholipid-Bestimmung in Fruchtwasser - Vergleich zweier Bestimmungsmethoden. In: Dudenhausen, J. W., E. Saling: Perinatale

\section{$\cdot 1$}

Medizin Band IV, 5. Deutscher Kongreß für Perinatale Medizin, Berlin, November 1972. Thieme, Stuttgart 1973

[8] Nakamura, J., J. F. Roux, E. G. Brown, A. Y. SwEET: Total lipids and the lecithin sphingomyelin ratio of amniotic fluid: An antenatal test of lung immaturity? Amer. J. Obstet. Gynec. 113 (1972) 363

[9] NeLson, G. H.: Relationship between amniotic fluid lecithin concentration and respiratory distress syndrome. Amer. J. Obstet. Gynec. 112 (1972) 827

[10] Saling, E.: Rangfolge des Einsatzes der verschiedenen Uberwachungsmethoden in der Spätschwangerschaft. In: Dudenhausen, J. W., E. Saling: Perinatale Medizin Band IV, 5. Deutscher Kongreß für Perinatale Medizin, Berlin, November 1972. Thieme, Stuttgart 1973

[11] Spellacy, W. N., F. Buhr, W. C. Buhi: Amniotic fluid lecithin/sphingomyelin ratio as an index of fetal maturity. Obstet. and Gynec. 39 (1972) 852

[12] Wolff, F., M. Masson, H. Frenked, C. Koeht, P. LeIssNer, A. R. Schick: Das Verhältnis Lecithin/ Sphingomyeline in der Bestimmung der fetalen Lungenreife und seine Abhängigkeit zum Schwangerschaftsalter. In: Dudenhausen, J. W., E. Saling: Perinatale Medizin Band IV, 5. Deutscher Kongreß für Perinatale Medizin, Berlin, November 1972. Thieme, Stuttgart 1973

Authors' address:

Dr. G. Kynast

Prof. Dr. E. Z. Saling

Unit for Perinatal Medicine

Free University of Berlin

Mariendorfer Weg 28-38

D-1000 Berlin 44

Germany 


\title{
Announcements
}

\section{The German Society for Perinatal Medicine will hold its}

\author{
VIth German Congress for Perinatal Medicine \\ with international participation.
}

28th November - 2nd December 1973

It will take place in the Berlin Congress Hall.

The themes of the Platform Discussions will be as follows:

1. Threatened early pregnancy (Diagnosis, consequences, prognosis)

2. Practical questions about tocolysis in pregnancy

3. Incorrect results and misleading evaluations of cardiotocography and fetal blood sampling

4. Supervision and management of the second stage according to modern developments

5. Topical questions of the care of the pregnant woman, the fetus and the neonate in bloodgroup incompatibility

6. Cooperation between in-patient and outpatient department and practising colleague in antenatal care

7. Glucose metabolism in the fetus and neonate with special reference to hypoglycemia

8. Transport of infants at risk from the obstetric ward to the pediatric ward:
a) Transference of data
b) Means of transport
c) Other additional conditions and measures

9. Infant and maternal mortality in West Germany: Population statistics, causal interrelations, prognoses.

The following Work Groups will be conducted:

1. Staff and technical equipment of intensive-care units for premature babies and neonates at risk

2. The statistics of Perinatal Medicine - an international comparison
3. Data processing in obstetrics and perinatal medicine

\section{Prospective Special Lectures:}

1. Problems of preventive screening examinations in the neonatal period

2. Fetal pharmacology - problems arising for the clinician

3. Amnioncentesis in early pregnancy: Indications, technique, dangers

4. Estimation of placental function with radioisotopes

5. Practical importance of prostaglandins - critical evaluation

6. Topical questions in anesthetics and obstetrics

7. Present state of phototherapy in the newborn

8. Orthopedics and perinatal medicine

\section{Congress languages:}

The language of the congress is German.

However, all platform discussions and special lectures will be translated simultanesously into English.

\section{Address of the congress secretariat:}

Deutsche Gesellschaft für Perinatale Medizin

Mariendorfer Weg 28-38

D-1000 Berlin 44

Germany 
The 4th European Congress for Perinatal Medicine will be held in Prague, Czechoslovakia

from 28th - 31st August 1974,

under the patronage of the J. E. Purkyner Medical Society of Czechoslovakia

\section{Programme:}

Round-table discussions (plenary sessions):

1. Antenatal diagnosis of the "at risk" fetus during late pregnancy and labor.

Moderator: Prof. E. SALING, Berlin.

2. Premature delivery (prevention and management) and the preterm infant.

Moderator: Dr. P. DunN, Bristol.

3. The short and long term prognosis of perinatal complications.

Moderator: Prof.H.F.K. Prechtr, Groningen.

Free communications every afternoon in two sections.

\section{Congress languages:}

English, German, French and Russian with simultaneous interpretation in plenary sessions.

\section{Address of the congress secretariat:}

Czechoslovak Medical Society J. E. Purkyn, 4th European Congress of Perinatal Medicine, Sokolská 31, 120-26 Praha 2, Czechoslovakia

Cables: Purkynemedical Praha, Czechoslovakia

\section{Organizing Committee:}

K. PolĀ̌̌cEK, M.D.

Z. Štembera, M.D

Secretary General

President
V. Šabata, M.D.

Organizing Secretary 